\title{
Benign Pleural Neoplasm
}

National Cancer Institute

\section{Source}

National Cancer Institute. Benign Pleural Neoplasm. NCI Thesaurus. Code C3603.

A non-metastasizing neoplasm that arises from the pleura. Representative examples include lipoma and adenomatoid tumor. 